\title{
ANALYSIS OF APPROACHES TO THE DEVELOPMENT AND VALIDATION OF THE METHODS OF ANALYSIS OF MELDONIUM IN DRUGS AND BIOLOGICAL LIQUIDS
}

\footnotetext{
Introduction. Analytical methods development and validation play important roles in the discovery, development and manufacture of pharmaceuticals. Method development is the process of proving that an analytical method is acceptable for use to measure the concentration of an API in a specific compounded dosage form which allow simplified procedures to be employed to verify that an analysis procedure, accurately and consistently will deliver a reliable measurement of an active ingredient in a compounded preparation. The analytical method validation is essential for analytical method development and tested extensively for specificity, linearity, accuracy, precision, range, detection limit, quantization limit, and robustness. In summary, analytical method development and validation allows to confirm that an accurate and reliable potency measurement of a pharmaceutical preparation can be performed. Search criteria was method development of meldonium. Literature survey has been done in range of years 1990-2019 to make the review updated and comprehensive and to show the new approaches to the development of the methods of analysis of meldonium. The sources were world recognized journals and key words used as filter were meldonium, spectrophotometric method, high-performance liquid chromatography, quantitative analysis, method development, validation.

The aim of the study - to analyze the approaches of the development and validation of the methods of analysis of meldonium in drugs and biological liquids.

Conclusions. In light of the benefits discussed in this review, we can conclude that analysts are constantly working on developing new methods of analysis of meldonium in drugs and biological liquids and on their optimization in order to save time and consumables, which also ensures the efficiency of the developed methodology. Literature survey revealed that a number of methods have been reported for estimation of meldonium individually. However, there is no analytical methods reported for the simultaneous analysis of these drugs in a combined dosage formulation.

KEY WORDS: meldonium; spectrophotometric method; high-performance liquid chromatography; quantitative analysis; method development; validation.
}

Nowadays, metabolic therapy is an important component of the treatment of virtually any disease of the internal organs. Drugs affecting the metabolic processes in the heart, brain, liver, muscles, are widely prescribed by general practitioners and narrow specialists. A special place among them take cardioprotectors - a group of drugs that improves metabolic processes in ischemic myocardium, increase resistance to hypoxia, eliminate cellular metabolism disorders. To the well-known and recognized by clinicians cardioprotectors also belongs meldonium, sold under the brand name Mildronate, is a performance-enhancing drug that is the source of much debate in the world of sports doping. Initially designed in Latvia for use in animals, the World Anti-Doping Agency (WADA) has indicated that this drug is banned in Olympic sports. Meldonium is primarily manufactured by a Latvian (c) M. M. Horyn, L. S. Logoyda, 2019. drug company called Grindeks. It is also known as Mildronāts, Quaterine, trimethylhydrazinium propionate, and 3-(2,2,2-trimethylhydraziniumyl)propionate (Fig.). The pharmaceutical company Grendiks, based in Latvia, produced meldonium. With sales of the drug reaching 56 million euros in 2013, it is one of Latvia's biggest medical exports. According to the designer of the drug, Ivar Kalvins, chair of the scientific board of the Latvian Institute of Organic Synthesis, meldonium was created to increase the capacity of the body to carry oxygen. Prior to the use of meldonium for cardiac health issues, the company shipped large quantities of the drug to Soviet troops in Afghanistan between 1979 and 1989. Due to the mountainous terrain of Afghanistan, Soviet soldiers would take meldonium to increase their endurance in the oxygen-reduced air while carrying large backpacks [1-4]. 
<smiles>C[N+](C)(C)NCCC(=O)[O-]</smiles>

Fig. The chemical structure of meldonium.

It is licensed throughout Eastern Europe and Central Asia for a number of conditions, including cardiac complaints. Meldonium remains on the WADA list of banned drugs in sports. A number of athletes from the United States, Russia, and Europe are currently facing bans for using meldonium. Most recently, this includes Alexander Krushelnitsky, who won medals in curling for Russia at the most recent Winter Olympics. The Olympic committee stripped him of his medals and banned him from participation in his sport for 2 years. WADA added meldonium to their list of banned substances in 2016 because of "evidence of its use by athletes with the intention of enhancing performance". They class meldonium as a metabolic modulator in the same bracket as insulin. Meldonium is a fatty acid oxidation inhibitor, and it is now principally used for heart conditions, such as angina, heart attack, heart failure, and others. A study in 2005 found that meldonium, in combination with an angiotensin-converting enzyme inhibitor called lisinopril, improved exercise capability and peripheral circulation for individuals with chronic heart failure. A Chinese study group tested meldonium for its efficacy in treating acute ischemic stroke, finding it to be as effective as cinepazide, a vasodilator that people in China commonly use to treat stroke. In some countries, people use meldonium to treat problems with circulation in the brain.

Meldonium is a structural analogue of gammabutyrobetamine. At the heart of the mechanism of action of the drug is the reduction in the amount of carnitine in the body, which in the conditions of oxygen insufficiency leads to inhibition of oxidation of fatty acids. Meldonium induces biosynthesis of nitric oxide, which promotes relaxation of smooth muscle of vessels, improves microcirculation and endothelial function. The therapeutic effect of the drug is due to the variety of its pharmacological effects. Meldonium is used in the treatment of various chronic cardio-vascular diseases and disorders of the cerebral circulation, as well as to improve mental and physical capacity. Pharmaceuticals based on it are manufactured by leading domestic and foreign pharmaceutical companies in the form of tablets, capsules and injection solutions. Consequently, there is a need to ensure the control of their quality by developing reliable and affordable methods of pharmaceutical analysis of meldonium in medicinal forms.
Search criteria was analytical method development for medicines containing meldonium. Literature survey war done in range of years 1990-2019 to make the review updated and comprehensive and to show the new approacheches to the development of the methods of analysis of meldonium. The sources were world recognized journals and key words used as filter were meldonium, method development, spectrophotometry, high performance liquid chromatography, validation.

Meldonium has been classified as a hydrazinium base of low molecular weight, and its determination is rather difficult. The State Pharmacopoeia of Ukraine (SPhU) does not have a monograph on the substance of meldonium dihydrate or on the prepared medical form. However, the substance meldonium dihydrate is described in the European Pharmacopoeia and the State Pharmacopoeia of the Russian Federation (SPRF). Thus, the SPRF XII recommends the quantitative determination of meldonium dihydrate by the acidimetry method in a non-aqueous medium with a potentiometric fixation of the end point of titration.

Historical development of methods for the quantitative determination of meldonium in substances and drugs is closely related to the development of analytical methods themselves and pharmaceutical analysis in general. Nowadays, the literature contains a large number of scientific papers devoted to the quantitative determination of meldonium in medical form [5-14].

Spectrophotometric method is widely used in the analysis of meldonium in substance and in mono- and combined drugs. Donchenko et al. proposed the spectrophotometric method of quantitative determination of meldonium dihydrate by the reaction with $\mathrm{p}$-chloranil. During the development of the method, the study of the interaction of meldonium dihydrate with $p$-chloranil was carried out. The factors that could influence the speed and completeness of the reaction, namely the nature and composition of the solvent, the concentration of the reagent, the temperature and stability of the reaction products in time, were studied. It was experimentally established that meldonium dihydrate reacts with $p$-chloranil in DMF medium to form the coloured reaction product with absorption maximum at $556 \mathrm{~nm}$. The proposed method was subjected to validation tests.

The method was validated for the parameters like linearity, precision, accuracy, robustness and range of application. Beer's law was performed at the concentration range of $8.00-20.00 \mathrm{mg} / 100 \mathrm{ml}$ with correlation coefficient 0.9995 . The requirements for linear dependence parameters are met, that is, the linearity of the method of quantitative 
determination of meldonium dihydrate is confirmed throughout the range of concentrations (60-140\%). Proposed method is suitable for use in laboratories for quality control of drugs and technical control departments of chemical and pharmaceutical enterprises. Görgens $C$ et al. developed the method for monitoring doping control urine samples using hydrophilic interaction liquid chromatography - high resolution/high accuracy mass spectrometry. Here, according to applicable regulations in sports drug testing, a full qualitative validation was conducted. The assay demonstrated good specificity, robustness ( $\mathrm{rRT}=0.3 \%$ ), precision (intra-day: 7.0-8.4\%; interday: 9.9-12.9\%), excellent linearity $(R>0.99)$ and an adequate lower limit of detection $(<10 \mathrm{ng} / \mathrm{mL}$ ).

Azaryan et al. proposed the method for determining meldonium in human urine, including sample preparation to analysis and analyte determination by HPLC with tandem mass spectrometric detection. For sample preparation, the procedure of "dilute-and-shoot" was used. The lower limit of the analytical range is $10 \mathrm{ng} / \mathrm{mL}$; the limit of detection is $7.5 \mathrm{ng} / \mathrm{mL}$; and the linearity range is 10 $250 \mathrm{ng} / \mathrm{mL}$. The proposed procedure is tested on real samples obtained from volunteers. A possibility of the direct analysis of urine samples after dilution is demonstrated; the limit of detection is $20 \mathrm{ng} / \mathrm{mL}$. The high sensitivity of the procedure ensures its use for the determination of meldonium in clinical diagnosis and doping control. A rapid and simple method based on ultra-performance liquid chromatography on a hydrophilic interaction chromatography column with tandem mass-selective detection (UPLC-MS/MS) to determine meldonium in human plasma was developed by Pidpruzhnykov et al. The calibration curve acquired in the range of $10-6000 \mathrm{ng} / \mathrm{mL}$ had quadratic form. Method validation proved the conformity of its properties (selectivity, matrix effect, lower limit of quantification, accuracy, precision and recovery) with the established requirements. The stability tests necessary for bioanalytical studies were performed. For the first time, the method was successfully applied to the bioequivalence studies of generic and brand name oral drugs of meldonium in capsules.

Based on data from 24 volunteers, it was determined that the mean pharmacokinetic curves of the drugs are characterized by a double peak profile. Zupanets et al. performed bioequivalence research of drugs, which contain trimethylgydrazonii propionatis - Vazonat and Mildronat. Results of the carried out research allow confirming, that according to the evidence medicine and a pharmacy, Vazonat and Mildronat have the identical efficiency and portability. Thus, it is possible to offer the specialists of applied medicine (doctors) and specialists of drugstores (managing drugstores, pharmaceutists of the first table, pharmacists) to carry out generic replacement Vazonat and Mildronat, based on the basic positions of evidence medicine and pharmacy. Juris Hmelnickis et al. developed the hydrophilic interaction chromatography for simultaneous separation of six impurities of mildronate substance. The possibility of separating the impurities of mildronate, an antiischemic drug, by hydrophilic interaction chromatography (HILIC) was investigated on different polar stationary phases (silica, amino, cyano and zwitterionic sulfobetaine).

The investigations have shown that HILIC is a useful alternative to reversed phase and ion-pair chromatography. The impact of HILIC separation conditions (acetonitrile content, buffer $\mathrm{pH}$ in mobile phase) on retention and selectivity has been systematically studied. Importance of these factors was found to be dependent on the structural properties of solutes. A HILIC method using a zwitterionic sulfobetaine stationary phase was developed and validated to determine six impurities in the drug substance. The method was validated in terms of specificity, limit of quantitation, limit of detection, linearity, accuracy and precision. Visych et al. performed the complex bioequivalence studies of generic and reference drugs of meldonium in form solid capsules of $250 \mathrm{mg}$ and $500 \mathrm{mg}$ by biowaiver procedure. Investigation of meldonium solubility and degree of penetration studies found that meldonium belongs to class I according to biopharmaceutical classification system. It was defined, that research objects belong to rapidly soluble drugs in all recommended dissolution medium. The similarity of dissolution profiles demonstrates the equivalence of generic and reference drugs of meldonium.

Prospects for further research. In light of the benefits discussed in this review, we can conclude that analysts are constantly working on developing new methods of analysis of meldonium in drugs and biological liquids and on their optimization in order to save time and consumables, which also ensures the efficiency of the developed methodology. Literature survey revealed that a number of methods have been reported for estimation of meldonium individually. However, there is no analytical methods reported for the simultaneous analysis of these drugs in a combined dosage formulation. It has been usefull in laboratories for quality control of drugs and technical control departments of chemical and pharmaceutical enterprises, laboratories for study pharmacokinetics and departments for registration of medicines by biowaiver procedure. 


\section{LITERATURE}

1. Dambrova M. Mildronate: Cardioprotective action through carnitine-lowering effect / M. Dambrova, E. Liepinsh, I. Kalvinsh // Trends in Cardiovascular Medicine. - 2002. - 12. - P. 275-279. doi: 10.1016/S10501738(02)00175-5

2. Multiple peaking phenomena in pharmacokinetic disposition / N. M. Davies, J. K. Takemoto, D. R. Brocks, J. A. Yáñez // Clinical Pharmacokinetics. - 2010. - 49. P. 351-377. doi: 10.2165/11319320-000000000-00000

3. EMEA/CHMP. Guideline on Validation of Bioanalytical Methods (Draft). EMEA/CHMP/EWP/192217/ 2009. European Medicines Agency/Committee for Medicinal Products for Human Use, 2009. Access mode : http://www.ema.europa.eu/docs/en_GB/document library/Scientific_guideline/2009/12/WC500018062.pdf (accessed 19 November 2009).

4. FDA/CDER. Guidance for Industry. Bioanalytical Method Validation. Food and Drug Administration/Center for Drug Evaluation and Research, 2001. Access mode : http://www.fda.gov/cder/guidance/4252fnl. (accessed 28 June 2010).

5. Evaluation of prevalence and control of risk factors for cardiovascular disease among the population and doctors (Ukrainian) / I. M. Gorbas, O. M. Barna, V. U. Sakalosh, M. A. Bakumenko // Drugs of Ukraine Plus. - 2010. - 1. - P. 4-9.

6. Application of hydrophilic interaction chromatography for simultaneous separation of six impurities of mildronate substance / J. Hmelnickis, O. Pugovičs, H. Kažoka [et al.] // Journal of Pharmaceutical and Biomedical Analysis. - 2008. - 48. - P. 649-656. doi: 10.1016/j.jpba.2008.06.011

7. Li K. Determination of free L-carnitine in human seminal plasma by high performance liquid chromatography with precolumn ultraviolet derivatization and its clinical application in male infertility / K. Li, W. Li, Y. Huang // Clinica Chimica Acta. - 2007. - 378. P. 159-163. doi: 10.1016/ j.cca.2006.11.008
8. Ultra-performance liquid chromatography-tandem mass spectrometric method for the determination of Artemisinin in rat serum and its application in pharmacokinetics / L. Li, D. Pabbisetty, P. Carvalho [et al.] // Journal of Chromatography B. - 2008. - 867. - P. 131137. doi: 10.1016/j.jchromb.2008.01.057

9. Lv Y. F. Determination of mildronate in human plasma and urine by liquid chromatography-tandem mass spectrometry / Y. F. Lv, X. Hu, K. S. Bi // Journal of Chromatography B. - 2007. - 852. - P. 35-39. doi: 10.1016/j.jchromb. 2006.12.031

10. Determination of mildronate by LC-MS/MS and its application to a pharmacokinetic study in healthy Chinese volunteers / Y. Peng, J. Yang, Z. Wang [et al.] // Journal of Chromatography B. - 2010. - 878. - P. 551556 doi: 10.1016/j.jchromb.2009.12.030

11. Sjakstea N. Mildronate: an antiischemic drug with multiple indications / N. Sjakstea, I. Kalvinsh // Pharmacologyonline. - 2006. - 1. - P. 1-18. Access mode : http:// www.unisa.it/download/1966_145_754131398_1_ Sjakste.pdf.

12. The State Pharmacopoeia of Russian Federation, 12th edn, part 1. Office of the Scientific Center of Expertise of Medical Products, Russian Federation, 2008.

13. Zupanets I. A. The bioequivalence studying of drugs Vazonat and Mildronat: basis of evidence medicine and pharmacy (Ukrainian) / I. A. Zupanets, N. P. Bezuglaja, Y. V. Podpruzhnikov // Drugs of Ukraine. - 2009. - 5. P. 72-75. - Access mode : http://www.health-medix.com/ articles/liki_ukr/2009-08-01/LU_Zupanets.indd.pdf (accessed $0 \overline{1}$ August 2009).

14. The study of trimethylhydrazinium propionate pharmacokinetic (Ukrainian) / I. A. Zupanets, Y. V. Pidpruzhnykov, M. J. Golovenko [et al.] // Clininal Phamacy. 2010. - 14. - P. 18-23. Access mode : http://www.nbuv. gov.ua/portal/chem_biol/klph/2010_1/18-23.pdf (accessed 01 April 2010).

\section{REFERENCES}

1. Dambrova, M., Liepinsh, E., \& Kalvinsh, I. (2002). Mildronate: Cardioprotective action through carnitinelowering effect. Trends in Cardiovascular Medicine, 12, 275-279. doi: 10.1016/S1050-1738(02)00175-5

2. Davies, N.M., Takemoto, J.K., Brocks, D.R., \& Yáñez, J.A. (2010). Multiple peaking phenomena in pharmacokinetic disposition. Clinical Pharmacokinetics, 49, 351-377. doi: 10.2165/11319320-000000000-00000

3. EMEA/CHMP. Guideline on Validation of Bioanalytical Methods (Draft). EMEA/CHMP/EWP/192217/ 2009. European Medicines Agency/Committee for Medicinal Products for Human Use, 2009. Retrieved from: http://www.ema.europa.eu/docs/en_GB/document library/Scientific_guideline/2009/12/WC500018062.pdf (accessed 19 November 2009).

4. FDA/CDER. Guidance for Industry. Bioanalytical Method Validation. Food and Drug Administration/Center for Drug Evaluation and Research, 2001. Retrieved from: http://www.fda.gov/cder/guidance/4252fnl. (accessed 28 June 2010).

5. Gorbas, I.M., Barna, O.M., Sakalosh, V.U., \& Bakumenko, M.A. (2010). Evaluation of prevalence and control of risk factors for cardiovascular disease among the population and doctors (Ukrainian). Drugs of Ukraine Plus, 1, 4-9.

6. Hmelnickis, J., Pugovičs, O., Kažoka, H., Viksna, A., Susinskis, I., \& Kokums, K. (2008). Application of hydrophilic interaction chromatography for simultaneous separation of six impurities of mildronate substance. Journal of Pharmaceutical and Biomedical Analysis, 48, 649-656. doi: 10.1016/j.jpba.2008.06.011

7. Li, K., Li, W., \& Huang, Y. (2007). Determination of free L-carnitine in human seminal plasma by high performance liquid chromatography with precolumn 
ultraviolet derivatization and its clinical application in male infertility. Clinica Chimica Acta, 378, 159-163. doi: 10.1016/ j.cca.2006.11.008

8. Li, L., Pabbisetty, D., Carvalho, P., Avery, M., Williamson, J.S., \&Avery, B.A. (2008). Ultra- performance liquid chromatography-tandem mass spectrometric method for the determination of Artemisinin in rat serum and its application in pharmacokinetics. Journal of Chromatography B, 867, 131-137. doi: 10.1016/j. jchromb.2008.01.057

9. Lv, Y.F., Hu, X., \& Bi, K.S. (2007). Determination of mildronate in human plasma and urine by liquid chromatography-tandem mass spectrometry. Journal of Chromatography B, 852, 35-39. doi: 10.1016/j.jchromb. 2006.12.031

10. Peng, Y., Yang, J., Wang, Z., Wang, J., Liu, Y., Luo, Z., \& Wen, A. (2010). Determination of mildronate by LC-MS/MS and its application to a pharmacokinetic study in healthy Chinese volunteers. Journal of Chromatography $B$, 878, 551-556. doi: 10.1016/j.jchromb. 2009.12.030
11. Sjakstea, N., \& Kalvinsh, I. (2006). Mildronate: an antiischemic drug with multiple indications. Pharmacologyonline, 1, 1-18. Retrieved from: http:// www.unisa. it/download/1966_145_754131398_1_Sjakste.pdf.

12. The State Pharmacopoeia of Russian Federation, 12th edn, part 1. Office of the Scientific Center of Expertise of Medical Products, Russian Federation, 2008.

13. Zupanets, I.A., Bezuglaja, N.P., \& Podpruzhnikov, Y.V. (2009). The bioequivalence studying of drugs Vazonat and Mildronat: basis of evidence medicine and pharmacy (Ukrainian). Drugs of Ukraine, 5, 72-75. Retrieved from: http://www.health-medix.com/articles/liki ukr/2009-08-01/LU_Zupanets.indd.pdf (accessed $0 \overline{1}$ August 2009).

14. Zupanets, I.A., Pidpruzhnykov, Y.V., Golovenko, M.J., Bezugla, N.P., \& Borisjuk, I.Y. (2010). The study of trimethylhydrazinium propionate pharmacokinetic. Clininal Phamacy, 14, 18-23. Retrieved from: http://www. nbuv.gov.ua/portal/chem_biol/klph/2010_1/18-23.pdf (accessed 01 April 2010).

\section{АНАЛІЗ ПІДХОДІВ ДО РОЗРОБКИ ТА ВАЛІДАЦІЇ МЕТОДІВ АНАЛІЗУ МЕЛЬДОНІЮ В ЛІКАРСЬКИХ ЗАСОБАХ І БІОЛОГІЧНИХ РІДИНАХ}

\section{Резюме}

Вступ. Розробка і валідація аналітичних методів відіграють важливу роль у створенні, розробці та виробництві лікарських засобів. Розробка методики аналізу-підтвердження того, що аналітичний метод придатний для використання з метою визначення концентрації АРІ в комбінованій лікарській фрормі. Це дає можливість застосовувати спрощені процедури для перевірки того, що методика аналізу точно $і$ послідовно забезпечить надійне визначення активного фрармацевтичого інгредієнта в лікарському засобі. Валідація аналітичної методики має важливе значення для розробки аналітичних методів, $і$ ії широко перевіряють на специфрічність, лінійність, правильність, прецизійність, робасність. Таким чином, розробка та валідація аналітичних методів дозволяють підтвердити можливість точного і надійного визначення ефрективності активного фрармацевтичного інгредієнта в лікарських засобах та біологічних рідинах. Критерієм пошуку був аналітичний метод розробки мельдонію. Огляд літератури проводили в період 1990-2019 рр., щоб зробити його оновленим та всеосяжним і показати нові підходи до розробки методів аналізу мельдонію. Джерелами були всесвітньо відомі журнали, а ключовими словами в якості фрільтра мельдоній, спектрофотометричний метод, високоефективна рідинна хроматографрія, кількісне визначення, розробка методики, валідація.

мета дослідження - проаналізувати підходи до розробки та валідації методів аналізу мельдонію в лікарських засобах і біологічних рідинах.

Висновки. У світлі переваг, які обговорювали в цьому огляді, можна зробити висновок, що хіміки-аналітики постійно працюють над розробкою нових методів аналізу мельдонію в лікарських засобах і біологічних рідинах та їх оптимізацією з метою економії часу і витратних матеріалів, що також забезпечує ефрективність розробленої методології. Дослідження літератури показало, що для аналізу мельдонію індивідуально або в комбінації з іншими лікарськими засобами існує ряд методів. Однак немає аналітичних методів для одночасного аналізу цих препаратів у комбінованій лікарській фрормі.

КЛЮЧОВІ СЛОВА: мельдоній; спектрофотометричний метод; високоефективна рідинна хроматографрія; кількісний аналіз; розробка методики; валідація. 


\section{АНАЛИЗ ПОДХОДОВ К РАЗРАБОТКЕ И ВАЛИДАЦИИ МЕТОДОВ АНАЛИЗА МЕЛЬДОНИЯ В ЛЕКАРСТВЕННЫХ СРЕДСТВАХ И БИОЛОГИЧЕСКИХ ЖИДКОСТЯХ}

\section{Резюме}

Вступление. Разработка и валидация аналитических методов играют важную роль в создании, разработке и производстве лекарственных средств. Разработка методики анализа - подтверждение того, что аналитический метод является приемлемым для использования с челью определения концентрации API в комбинированной лекарственной форме. Это позволяет применять упрощенные процедуры для проверки того, что методика анализа точно и последовательно обеспечит надежное определение активного фрармацевтического ингредиента в лекарственном средстве. Валидация аналитической методики имеет важное значение для разработки аналитических методов, и ее широко проверяют на специяричность, линейность, правильность, прецизионность, робасность. Таким образом, разработка и валидация аналитических методов позволяют подтвердить возможность точного и надежного определения эффрективности активного орармацевтического ингредиента в лекарственных средствах и биологических жидкостях. Критерием поиска был аналитический метод разработки мельдония. Обзор литературы проводили в период 1990-2019 г2., чтобы сделать его обновленным и всеобъемлющим и показать новые подходы к разработке методов анализа мельдония. Источниками были всемирно известные журналы, а ключевыми словами в качестве фрильтра - мельдоний, спектрофотометрический метод, высокоэффрективная жидкостная хроматография, количественное определение, разработка методики, валидация.

Цель исследования - проанализировать подходы к разработке и валидации методов анализа мельдония в лекарственных средствах и биологических жидкостях.

Выводы. В свете преимуществ, которые обсуждали в этом обзоре, можно сделать вывод, что химики-аналитики постоянно работают над разработкой новых методов анализа мельдония в лекарственных средствах и биологических жидкостях и их оптимизацией с целью экономии времени и расходных материалов, что также обеспечивает эффрективность разработанной методологии. Исследование литературы показало, что для анализа мельдония индивидуально или в комбинации с другими лекарственными средствами существует ряд методов. Однако отсутствуют аналитические методы для одновременного анализа этих препаратов в комбинированной лекарственной форме.

КЛЮЧЕВЫЕ СЛОВА: мельдоний; спектрофотометрический метод; высокоэффективная жидкостная хроматография; количественный анализ; разработка методики; валидация.

Address for correspondence: L. S. Logoyda, I. Horbachevsky Ternopil National Medical University, Maidan Voli, 1, Ternopil, 46001, Ukraine, e-mail: logojda@tdmu.edu.ua. 